\title{
根性坐骨神経痛の非観血的療法
}

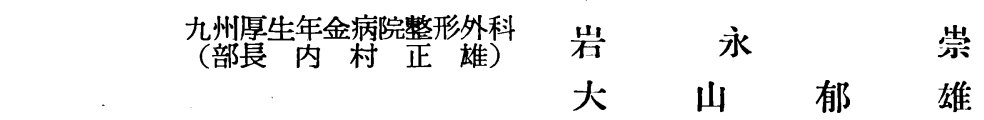

\section{Conservative Treatment of Low Back Pain}

by

\section{T. Iwanaga \& I. Ooyama}

Kyushu Welfare Pension Hospital

腹痛, 或いは所謂坐骨神䅅痛は, いつれの病院でも 大きな比率を占め, 労働能力の隇少による社会的意義 は看過し得ない。吾々は従来腰痛症, 或いは根性坐骨 神経痛に対し, 各種の薬物療法, 電気潦法, マッサー 沙等理学的療法, 或いは Lumbagoband の使用等を 行つて来なが，満足すべき結果を得ていない。従つて 保存的に治療して治瘾せぬ重症例に対しては，椎弓切 除術等の観血的療法を施行しているが，之に伴う硬膜 癒着その他の神経障碍を続発する危険が少く無い。又 幸に良好な経過をたどる場合にも，脊椎骨の一部除去 等の為に, 体重支持に対して弱点を形成し, 重労働に 復帰し得ざる例が決して少数ではない。

之等の事情により，他に有効な治療法を探究して， 危険の度が少く，又従来あまり重視されなかつた骨盤 斢引及び Manipulation を採用したのである。

骨盤轶引は，疼痛の鎮静に相当の効果を認められて 居り, 胸腰椎伸展位, 前屈位及び反張位の星引法があ る。単に疼痛の鎮静除去の立場よりすれば, 前屈位牽 引が最も効果的であるので，下肢と上体とを挙上した 半届曲位に於て，吊環を附した率引用腹帯を介し，左 右計 $10 \mathrm{~kg}$ の重垂率引を行つた。

Manipulation は, 徒手整復術と訳されているが, 後述の理由によつてこの語は適当では無い。この手技 は既にヒポクラテスの著書に現れている由で，欧米に 於ては古くよりその効果を誌められ，Mc Conville, Zuckschwerdt, Friberg 等之に関する発表も少くな い。我国に於ては未だ報告が無くて，指圧療法やマッ サージと共に，民間療法の一つとして行われている様 子であるが，本法によつて腰痛の治瘉する事のあるの は見逃し得ない。

この Manipulation は 3 種に大別できる。即ち前彎
強制法, 後彎強制法及び捻転法である。

1. 前瓶強制法は腹臥位で患側下肢を股関節に於て 外転，過伸展し，同時に腰仙関節部を反対側腹方に短 く強く衝撃的に圧迫する(図 1 )。又カンバス上に腹臥 せしめ, このッンバスを徐々に弛めて, 䁏椎の強い前 彎位を取らせる方法もある(Ventralen Durchhang)。

第 1 単 前彎强制法

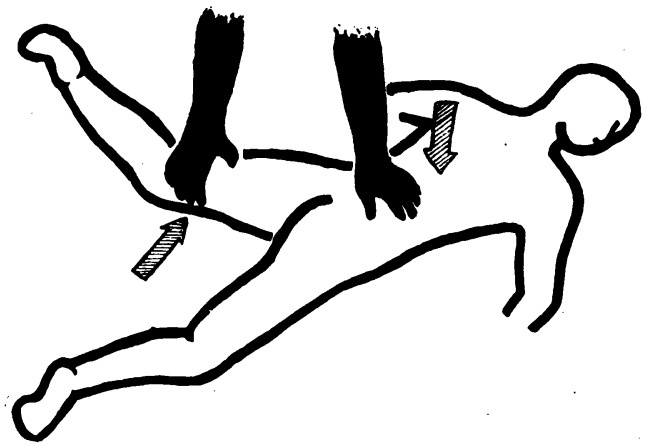

第 2 汹 捻 轉 法

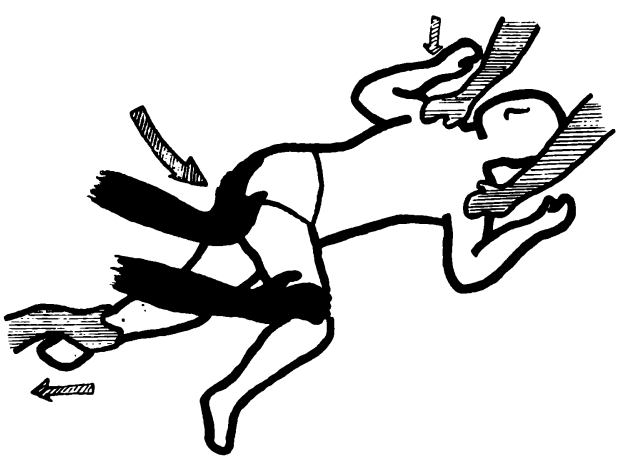

2. 後彎強制法は, 背臥位で両下肢を伸展し,ラセ グ症候を試みる特の如く, 両下肢を同時に举上して腰 
椎部を強く前届する。或いは，下半身を Bett より乗 出して腹卧し，下肢を床上に急激に落す。

3. 捻転法, 背臥位で患 側肩胛部を Bett に圧迫 し，健側足関節部を強く足方に毫引せしめ，術者は患 側大服を持つて强く届曲内転内旋する（図 2 ）。

Manipulation は全て硬いBett 上で, 全身の緊張 を除き，筋肉の算張を全く弛緩させた瞬間に行う。こ の時, 腰椎部にゴクッと音を感じる事がある。患側に
次で健側も同様の事を行 5。本法は全身政酔下に行 5 場合が多い。(Mensor, Mc Conville, Weiss) 然し Ewer は麻酔下の施行は神経麻㽻を起す佨険があり， 又骨折等の事故を防ぐ為に，無麻䣲で行 5 べぎま ると主張している。

Mensor は入院後 3〜4 日間, 両下腿の絆創育帮引 を行つた後に，捻転法による Manipulationを行い， 爾後 5 日〜 2 週間の率引を行つて, 腰部固定コルセッ

表 1 急激 発 症 例 ( $A$ 群)

\begin{tabular}{|c|c|c|c|c|c|c|c|c|c|c|c|c|}
\hline \multirow{2}{*}{$\begin{array}{l}\text { 症 } \\
\text { 例 } \\
\text { 番 } \\
\text { 是 }\end{array}$} & \multirow[b]{2}{*}{ 症例 } & \multirow{2}{*}{$\begin{array}{cc}\text { 発 } & \text { 治 } \\
\text { 病 } & \text { 療 } \\
\text { 後 } & \text { 沦 } \\
& \text { 期 } \\
\text { 間 }\end{array}$} & 術 & 前 & 所 & 見 & \multirow{2}{*}{$\begin{array}{cl}\text { 稚 } & \text { マ効 } \\
& = \\
\text { プ } & \\
\text { ラ } \\
\text { チ } \\
\text { オ } \\
\text { 音 ン果 }\end{array}$} & \multirow{2}{*}{$\begin{array}{l}\text { 骨 期 } \\
\text { 盤 } \\
\text { 第 } \\
\text { 引 間 }\end{array}$} & \multirow{2}{*}{\multicolumn{3}{|c|}{ 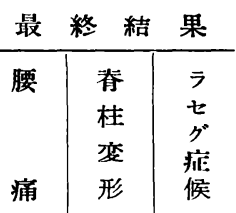 }} & \multirow{2}{*}{$\begin{array}{l}\text { 成 } \\
\text { 績 } \\
\text { 判 } \\
\text { 定 }\end{array}$} \\
\hline & & & $\begin{array}{c}\text { 下 } \\
\text { 肢 } \\
\text { 痛 }\end{array}$ & $\begin{array}{l}\text { ラ } \\
セ \\
\text { グ } \\
\text { 症 } \\
\text { 候 }\end{array}$ & $\begin{array}{l}\text { 脊 } \\
\text { 渾制 } \\
\text { 動限 }\end{array}$ & $\begin{array}{l}\text { 桂 } \\
\text { 变 } \\
\text { 形 }\end{array}$ & & & & & & \\
\hline 1 & & $1 \mathrm{M}$ & - & - & + & + & - & $3 W$ & - & - & - & 優 \\
\hline 2 & & $20 \mathrm{~T}$ & + & - & - & + & $\theta$ 良 & 6 & + & + & - & 良 \\
\hline 3 & & $2 T$ & - & + & H & H & $\Theta$ 良 & 2 & + & - & - & 優 \\
\hline 4 & & $1 \mathrm{M}$ & + & $40^{\circ}$ & + & - & $\Theta$ 優 & 3 & - & - & - & 優 \\
\hline 5 & & $1 \mathrm{~T}$ & - & $80^{\circ}$ & $H$ & $H$ & (丹 優 & 3 & - & - & - & 優 \\
\hline 6 & & $5 \mathrm{~T}$ & - & + & + & + & - & 5 & - & - & - & 優 \\
\hline 7 & & $1 \mathrm{~T}$ & + & $40^{\circ}$ & + & H & $\oplus$ 優 & 3 & - & + & - & 良 \\
\hline 8 & & $1 \mathrm{M}$ & - & - & + & - & - & 3 & + & - & + & 優 \\
\hline 9 & & $3 \mathbf{M}$ & + & $45^{\circ}$ & + & - & $\oplus$ 可 & 6 & - & - & $60^{\circ}$ & 产 \\
\hline 10 & & $2 \mathrm{M}$ & + & $70^{\circ}$ & $H$ & + & $\bar{\Theta}$ 可 & 3 & + & + & + & 可 \\
\hline 11 & & $1 \mathrm{~T}$ & + & $H$ & $H$ & $H$ & - & 2 & - & + & - & 優 \\
\hline 12 & & $1 \mathrm{~T}$ & - & $30^{\circ}$ & H & $H$ & $\Theta$ 良 & 3 & - & - & - & 優 \\
\hline 13 & & $1 \mathrm{~T}$ & + & $60^{\circ}$ & $H$ & H & $\Theta$ 良 & 2 & - & + & - & 優 \\
\hline 14 & & $1 \mathrm{~T}$ & - & $70^{\circ}$ & H & $H$ & $\Theta$ 可 & 8 & - & + & - & 優 \\
\hline 15 & & $2 \mathrm{~T}$ & + & $30^{\circ}$ & H & H & $\Theta$ 可 & 3 & + & - & - & 優 \\
\hline 16 & & $1 \mathrm{~J}$ & - & $70^{\circ}$ & + & $H$ & 丹 良 & 5 & - & + & $70^{\circ}$ & 良 \\
\hline 17 & & $1 \mathrm{~J}$ & + & $60^{\circ}$ & - & - & $\Theta$ 良 & 1 & - & - & $80^{\circ}$ & 良 \\
\hline 18 & & $1 \mathrm{M}$ & - & + & - & + & $\Theta \Theta$ 可 & 5 & - & - & - & 優 \\
\hline 19 & & $3 \mathrm{M}$ & + & $30^{\circ}$ & + & - & ( 可 & 1 & + & - & + & $\begin{array}{c}\text { 人院中 } \\
\text { 良 }\end{array}$ \\
\hline 20 & & $2 \mathrm{~T}$ & - & $70^{\circ}$ & H & $H$ & $\Theta$ 優 & - & + & - & - & 良 \\
\hline 21 & & $1 \mathrm{~T}$ & - & + & H & $H$ & $\theta$ 優 & - & - & - & - & 優 \\
\hline 22 & & $4 \mathrm{~T}$ & - & $30^{\circ}$ & $H$ & $\neq$ & $\Theta$ 可 & 1 & + & + & + & 可 \\
\hline 23 & & $10 \mathrm{~T}$ & - & - & + & - & - & 2 & & 腰 $\hat{5}$ & 筋 炎 & 不 可 \\
\hline
\end{tabular}


表 2 緩 徐 発 㾬 例 (B群)

\begin{tabular}{|c|c|c|c|c|c|c|c|c|c|c|c|c|c|c|}
\hline 痽 & & & & 発 治 & 䘕 & 前 & 所 & 見 & 又 効 & 骨 & 最 & 終 結 & 果 & 成 \\
\hline $\begin{array}{l}\text { 例 } \\
\text { 番 } \\
\text { 是 }\end{array}$ & 患 & 者 & 名 & $\begin{array}{c}\text { 痛 療 } \\
\text { 後 沦 } \\
\text { 期 } \\
\text { 間 }\end{array}$ & $\begin{array}{l}\text { 下 } \\
\text { 肢 } \\
\text { 痛 }\end{array}$ & $\begin{array}{l}\text { ラ } \\
\text { 号 } \\
\text { 庭 } \\
\text { 候 }\end{array}$ & $\begin{array}{l}\text { 運制 } \\
\text { 動限 }\end{array}$ & $\begin{array}{l}\text { 柱 } \\
\text { 変 } \\
\text { 形 }\end{array}$ & 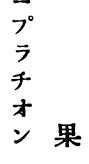 & 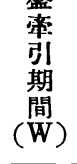 & $\begin{array}{l}\text { 腰下 } \\
\text { 痛肢 } \\
\text { 情痛 }\end{array}$ & $\begin{array}{l}\text { 脊 } \\
\text { 桂 } \\
\text { 変運 } \\
\text { 形動 }\end{array}$ & $\begin{array}{l}\text { j } \\
t \\
n^{\circ} \\
\text { 舱 } \\
\text { 候 }\end{array}$ & $\begin{array}{l}\text { 績 } \\
\text { 制 } \\
\text { 定 }\end{array}$ \\
\hline 1 & & & & 10月 & - & $60^{\circ}$ & - & + & - & 3 & - & - & - & 優 \\
\hline 2 & & & & 6月 & - & + & + & $H$ & 優 & 3 & - & - & - & 優 \\
\hline 3 & & & & 3年 & $H$ & $40^{\circ}$ & + & + & - & 2 & + & - & 80 & 良 \\
\hline 4 & & & & 1月 & + & $40^{\circ}$ & $H$ & H & 良 & 7 & - & - & - & 優 \\
\hline 5 & & & & 8月 & + & $60^{\circ}$ & - & - & - & 5 & - & - & + & 良 \\
\hline 6 & & & & 3月 & - & + & - & - & 食 & 8 & + & - & - & 良 \\
\hline 7 & & & & 3月 & + & $70^{\circ}$ & + & + & 優 & 6 & + & - & - & 優 \\
\hline 8 & & & & 6月 & + & - & + & + & 可 & 6 & + & - & - & 良 \\
\hline 9 & & & & 10月 & - & $70^{\circ}$ & H & $H$ & 可 & 3 & + & + & + & 良 \\
\hline 10 & & & & 3月 & + & $70^{\circ}$ & + & - & - & $4 T$ & + & - & 80 & 不 可 \\
\hline 11 & & & & 20年 & - & + & H & $H$ & 可 & 3 & - & - & - & 優 \\
\hline 12 & & & & 6月 & + & $60^{\circ}$ & + & - & oif & 2 & + & - & + & 手術, 可 \\
\hline 13 & & & & 1年 & - & - & - & $H$ & - & 1 & + & - & - & 可 \\
\hline 14 & & & & 1年 & + & $50^{\circ}$ & + & + & - & 1 & + & + & + & $\begin{array}{l}\text { 手街 } \\
\text { 不可 }\end{array}$ \\
\hline 15 & & & & 2年 & - & + & + & - & - & 1 & + & - & + & $\begin{array}{c}\text { 人院中 } \\
\text { 可 }\end{array}$ \\
\hline 16 & & & & 5月 & - & $30^{\circ}$ & + & - & 可 & 3 & + & - & + & 良 \\
\hline 17 & & & & 1月 & + & $45^{\circ}$ & + & + & 優 & 1 & + & - & 40 & $\begin{array}{c}\text { 入院中 } \\
\text { 優 }\end{array}$ \\
\hline 18 & & & & 1月 & + & $80^{\circ}$ & - & - & 可 & 3 & + & - & 80 & $\begin{array}{c}\text { 入院中 } \\
\text { 可 }\end{array}$ \\
\hline 19 & & & & 2年 & + & $60^{\circ}$ & + & - & - & $2 \mathrm{H}$ & + & - & + & 可 \\
\hline 20 & & & & 1年 & + & + & + & - & - & $2 \mathrm{H}$ & + & - & + & 不 可 \\
\hline
\end{tabular}

トを装着している。吾々も此の方法を参考として，入 院後 4〜 5 日乃至 1 週間の骨船衰引を行つた後, ラボ ナール静注麻酷下, 或いは無麻酶で, 捻転法及び前彎 強制法を行い，その後 1 週間乃至 4 週間の骨船率引を 行つた。

骨般舜引のみで腰痛が著しく軽快, 又は消失する例 には Manipulation を行わなかつた。㕛外来に於ては 率引を行わずに, Manipulation の及を行つた例もあ る。

成績の判定は, 自覚的疼痛を主とし, 背柱变形及び 可動性，ラセグ氏症候，その他を参考として次の如く に定めた。
優 全く疼痛なし。又は時々腰痛あるも苦痛ではな い。脊柱変形は極軽徵。脊柱可動性の制限なし。ラセ グ症候陰性。

良 : 腰痛はあるが苦痛を訴えない。脊柱変形は著し く軽快。脊柱可動性の制限なし。ラセグ症候僅に緊張 感あり。

可 : 術前より稍軽快（事故による中止を含む）。

不可 : 増悪

表の如く，43例に行い，優及び良の成樍を得たもの は31例であつて, 可の 3 例も治療中であるが此の後, 良に向つている。又この中で，良及び可の例る他の治 潦法を併用して，限院時には極めて軽快している。 
発症の急激な $\mathrm{A}$ 群は, 徐々に発症した $\mathrm{B}$ 群より、良 い成績を得ている。即ち $\mathrm{A}$ 群 23 例中で, 13 例が優で あるのに対し， B 群では 20 例中 6 例のみが優となつ ている。発症後 1 週間以内に治療を開始した 12 例中 で，9例が優である。早期治療の重要な事を物語るも のである。但し，か〉る良好な経過を取る例は，放置 しても治瘳すべき運命であつたと考兄られない事子無 いが，長期の経過を経た B 群江頭例の如きも良い成績 を得て居り, 又殆ど全例が，一時的にせよ疼痛の軽快 を示す所より見て，単に時日の経過による恢復である とは考えられない。

骨船率引によつて, B 群江藤例, 古賀例は反つて増 悪し，率引を中止した。之等は高度の変形性脊椎症に よる脊酭神経の圧迫及び，腸腰筋炎の誤診であつた。

$\mathrm{B}$ 群藤本例, 及年び $\mathrm{A}$ 群藏脇例は, 屈曲位率引で堌悪 したが，水平伸展位率引によつて軽快した。

Manipulation のみについて見ると，29例に行つ て，8例は術後に疼痛その他の著しい軽快を見て居 り，他の 8 例は稍軽快し， 13 例には全く効果がなか つた。特に定形的 Hexenschuss の 2 例には，頓挫的 の好結果をあたらした。

然し Manipulation によつて一時軽快したが，再発 を訴えた 3 例があり，（A群金㭌，松山，B群河内） 之等は Laminektomie 及び Myelographie によつ て，椎間板へルニヤ及び硬膜癒着を発見した。

考荣 半届位骨盤牽引が, 腰痛の緩和に有力な手段 である事は，此所に示した成績によつて明かである。 何故に鎮痛的に作用するかついては，明かな実験的根 拠を有しないが，その原因として考えられるあのは， 1. 喠引による持続的免荷, 即ち椎間板或いは脊椎関 節に加わる不適当な区迫の除去。萎縮せる背筋の伸展 が有力なる作用を及ぼす。 2 . 後彎位を取るために, 椎間後部が上下に開き, 脱出せる椎間板の還納が期待 できる。 3 . 強制的の安静も重要な因子であらう。

Manipulation によつて何が起るのであらうか? 脱 出せる椎間軟骨へルニヤの還納, 脊椎関節の亜脱臼の 整復，へルニヤにより圧迫された神経根の転移による 王迫の除去, 移動せる椎間板の復位等が考兄られてい る。

Pedersen によれば，椎間板，椎間関節，後絽靶帯 等には脊跹神経後技の知覚枝が分布し, 之等臟器の疼 痛刺战は，どの部分に加兄られても全て特殊的でない 腰痛と下肢痛とを起す様である。之によれば，何によ る効果であるかを確定する事は困難である。

しかし，亜脱臼なる状態が簡単に起り得るか否かは
疑問がある。又神経根が転移する為の疼痛軽減であ れ，この際その神経支配領域に疼痛，筋肉の痓等等が 起るべきであらうと思はれるが，吾々は一例もかかる 症候を見ていない。

Mensor 等は脱出せる椎間板の還納によつて，神経 根に対する圧迫が除かれると主張している。吾々は整 復の前后に Myelographie を3例に行つて見たが， 1 例に於て陰影缺損の極く僅かの縮少があるのではな いかと思われる他には明かな変化を発見しなかつた。 即ち椎管内に和ける明かな狭窄性変化に対しては，本 法は何かの作用を奴ぼすとは考光難い。Kloss 等によ れば腰椎の前後彎によつて, 脱出せる椎間軟骨が脊椎 管内に出没する場合があると云われ，か小る可動性一 ルニヤに対しては, 本法も有効であるかも知れない。

Ewer は変質せる椎間板が僅かに移動する事によつ て, 腰痛を起し， Manipulation によつて旧位に復 するのであらうと云つている。かつる小移動は僅の 外力, 例えば体の捻転等でも容易に起り得るし, 又 Manipulation の如き体外よりの力によつて旧に復す るのも可能であらう。又，小移動によつて椎間板に至 る知覚神経が刺战されて疼痛を起し，その復旧によつ て軽快する事は充分に考兊られる所である。

Manipulation に際して起るゴクッと云う音は何 によるるのか，未だ解明されていない。脱出せる椎間 板の整復音, 或いは亜脱臼の整復音である等と云われ ている。Mensorはこの音によつて成功したと見て いるが, McConville は成功の有無は穕音の有無によ らないと云つている。吾々の例でる，雉音を聞いた 場合の方が好結果を得る事が多いが, 全く雓音なくし て著明な軽快を示した例（A群田中例）むある。

以上の如く，骨般率引及び Manipulation は有力な 非観血的療法であるが，全く無症状となつた後にも再 発例があり，かつる例は Myelographie によつて著 明な陰影缺損を示し，手術を行つた。

之によつて見ると，Myelographie で著明な変化を 認める患者にる，一特的の効果を期待できるが，持続 的の治癒を得る事は出来ない。

最後に Manipulation は変形性脊椎症, 高血圧症, 心腎疾患, 及び骨柾渹症等高度な場合には禁忌であつ て，骨或いは神経損傷の危険があると云われる。

総括 吾々は根性坐骨神経痛に対して, 従来の薬物 的, 理学的, 及び観血的療法以外の方法を考究して, 骨盤率引，反び Manipulation を行つた。

骨盤率引は半届位腰椎後彎法を用いた。

Manipulation の各種の方法を紹介し，この中で捻 
転法と腰椎前颣側屈法とを用いた。

43 例について治療を行い，19 例に優秀な成績をお さめ，13 例に良好な結果を示し，他の 3 例で良好に 向つている。早期治療が良い。

Manipulation は29例に行つて 8 例に著明な疼痛 軽減を認め, 他の 8 他に術前より軽減を見た。

骨盤率引の奏功は, 脊椎椎間板, 椎間関節の不適当 な圧迫の除去, 背笳の緊張度の緩和, 椎間後部の離開,

強制的安静による。

Manipulation の効果は, 椎間板移動による疼痛 を，その復旧によつて軽减せしめると考える。或いは 椎間板の脱出による神経根圧迫を，椎間板還納によつ て除去すると思われる。

（御指導を賜つた内村部長に深謝する。）

\section{参考交献}

Ewer E.G. : J.B.J.S., 35-A No2, 347, 1953. 飯野三郎：整形外科， $3: 2 ， 155,1952$.

Kloss K. : Bruns' Beiträge Kl. Chir., 190 : 1, 911955.

Mc Conville B.E. : Am. J. Surg., 85, 335, 1953.

Mensor M.C. : J.B.J.S. 37-A, No5, 925, 1955

Pedersen H.E. : J.B.J.S. 38-A, No.2, 377, 1956.

Weiss J. : Arch. Orth. Chir. Bd47, 612, 1955.

\section{○坐骨神経痛に関する愁談}

\section{演題}

根性坐骨神経痛の非観血的嘹法

九州厚生年金病院岩永 崇・大山郁夫

天見数授 : 坐骨神経痛は整形外科医の弗箱でもある が, 又悩みの種でもある。その治療法について色々 皆様の御経験があれば。

難波雄哉（長大整形）：椎間板 ルニヤの位置とマニ プレーションの方法の撰択は如何にして居られる か。九州厚生年金, 岩永氏に打尋的する。

岩丞 崇（九州厚生年金）: 椎間板へルニヤを確認し
てはいない。へルニヤの還納が行われるとすれば可 動性へルニヤと考える。方法は捻転法及び無効であ るとみたとき過伸展法を行う。

藤川純俊（唐津）：上体を柱にく〉りつけ引張る方法 を行い, 腰部の音には注意, 音がすれば効果あつた ものとし次いでマッサージを行つている。40例の 中 28 例は非常によくなつている。1 例は却つて増 悪した。「宿違い」のときにも用いているが，この ときには頭部を引張りつ〉捻転すると $90^{\circ}$ 位 の迴旋 でゴッッと音がして治るよ5である。これには相当 よく効くように思う。再発したものには Glissonを 2 週間用いて治拯した。マニプレーションの Indikation として腰部捻挫，坐骨神経痛攻び寝違いが 挙げられうる。

天児数授 :こういう方法は誰がやつても安全なるの か。

岩永 : 私の症例では増覀例はない。文献では Lähmúng をきたしたり増悪することがあり，全麻でや るときは特にそういう危険があると思う。

天児教授：私の教室でもレ線撮影のとき急に下肢に㾝 痺を来たした者もある。

香月正紀（福岡更生指導所）：私自身腰痛を経験し， kyphotisch のギプスベットに寝ましたが，ギプス ベットが非常に有効であつたように思う。

Myelographie にて typisch のへルニヤを認め Laminektomie をしたが, 手術ではへルニヤはな く Lig. flavum の肥厚であつた。

永田恒久（大车田）：柔道整復師間では所謂ギックリ 腰, 坐骨神経痛に対して相当昔より多数の例に徒手 整復を行つている。有効なものもあり無効なものも あるようで，大して危険なことも起つていないよう です。

玉井教授 非常によくなる例もある。Indikation を 充分考えてやるべきだと思う。脊椎カリエス等にや つたら大変と思う。

伊藤教授：自然に治るのる可成りあるようだ。 